\title{
Enhancing Management Accounting Practices in Manufacturing Companies: A Special Reference to Top-level Management
}

\author{
Imran Khan \\ Lecturer, Department of Business Administration, Z. H. Sikder University of Science and Technology, Shariatpur, BANGLADESH \\ E-mail for correspondence: ikimran05@gmail.com
}

https://doi.org/10.18034/abr.v8i3.168

\begin{abstract}
Management accounting facilitates efficient business operation deploying different techniques that deal with the competitive edge. Organizations are facing new challenges regularly. To survive and expand business management always focus on different traditional and contemporary managerial techniques including. The management accounting techniques incorporate standard costing and variance analysis, traditional budgeting and cost volume profit analysis are commonly applied by managers which are now considered to be less useful in the competitive manufacturing environment. In order to achieve organizational goal and succeed in this present dynamic business environment, new techniques or strategies such as Just-In-Time (JIT), Activity Based Costing (ABC), Total Quality Management (TQM), process re-engineering, life cycle assessment and target costing would accelerate the capability of organizations by overcoming the acute global competition. This paper is an empirical study on manufacturing companies. Overall, the evidence reveals that most of the top-level management rely on so-called traditional techniques in their day to day activities than that of contemporary management accounting tools. However, new tools could accelerate business operations faster. Therefore, it is vivid that application of traditional management accounting techniques holds a strong position in the manufacturing arena. However, there is a good sign that some third generation businesses are trying to utilize new techniques slowly. Moreover, there exists some areas where proper attention is required to ensure best practice and utilization of management accounting mechanism. According to the findings, this paper provides some recommendations that might be useful to enhance the effectiveness and competitiveness of the top-level management and thus helpful in ensuring the practice of more sophisticated techniques in regular business operation.
\end{abstract}

Key words: Accounting, Management, Management Accounting Techniques, Accounting Practices

\section{INTRODUCTION}

To cope with competitive business environment management accounting has been playing a pivotal role. But the corporate world is changing its shape faster, and to overcome new challenges new techniques are to be applied. Different authors have proclaimed that traditional management accounting techniques such as standard costing, variance analysis, budgeting, and cost volume profit (CVP) analysis are no longer sufficient to be applied as planning and control instrument in the present vast manufacturing environment (Bromwich and Bhimani, 1994; Kaplan, 1983; Lucas, 1997). Further, many other scholars have predicted that the shorter product life cycles, advanced manufacturing technologies, decreasing emphasis on labor in the production process and global competition may lead to the demise of the above tools (Drury et al., 1993; Hilton, 2002). To cope with the present dynamic business environment organizations should connect their strategies with distinguishes techniques such as quality improvement, increased flexibility in meeting customers' requirements, reduced lead times, inventories and production cost (Lucas, 1997). Therefore, techniques or strategies such as just in time (JIT), activity-based costing (ABC), total quality management (TQM), process re-engineering, life cycle assessment, and target costing would substantially amplify the ability of organization to encounter their objectives. Simultaneously, it is not illogical to desire to investigate the extent to which contemporary and traditional management accounting mechanisms are embraced by the organizations in the emerging economies like Bangladesh. 
Through an extensive literature review, this study endeavors to analyze the management accounting practices in Bangladesh. One of the key objectives of this study is to identify and highlight the management accounting practices in Bangladesh. More particularly, is there a gap between the theory that is trained in our classrooms and management accounting practice (Scapens, 1988)? Moreover, the focus of earlier studies examining management accounting practices in other countries has been on individual Asian countries. For example, Abdul Rahman et al. (1998) and Sulaiman et al. (2002) surveyed Malaysian companies, Ghosh and Chan (1996) and Ghosh et al. (1987) examined companies in Singapore, Firth (1996) in China and Joshi (2001) in India.

Thus, the second focus of this study is to yield a contemporary analysis of management accounting techniques used in Bangladesh. It is considered that the synthesis of earlier studies will help supply an overview of management accounting practices in Bangladesh, thus enhancing the literature in the area of management accounting practices in Asia.

Earlier Willett et al.'s (1997) addressed concern that studies on management accounting practices in this region lag behind studies in financial accounting. This issue is relevant primarily because it is considered that accounting is a product of its environment (Choi and Mueller, 1992; Radebaugh and Gray, 1993). If, indeed, the environment shapes accounting, then one would expect there to be differences emerging in the adoption of the various management accounting tools by companies in these countries. The common practice of decision-making process comes from top-level management, and it is the primary responsibility of them to initiate the best suitable effective techniques for efficient management. There are few researches on the application of management accounting in manufacturing companies. However, there is no study to guide the top-level management. Therefore, this study provides an overview of current management accounting practices regarding top management level among different manufacturing companies and also advise them to consider some other tools as well.

\section{Objectives of the Study}

The principal objectives of the study are as follows:

- To understand the extent of management accounting techniques in manufacturing companies in Bangladesh

- To present the current scenario of practicing management accounting techniques in these companies of Bangladesh

- To examine the significance of traditional and contemporary management accounting techniques in decision making.

\section{Methodology OF the Study}

The study is mainly done by both primary and secondary data. To collect primary data, a structured questionnaire has been used. The respondents were the top management officials of the sample companies. The sample size consists of 26 public limited manufacturing companies (see Appendix I) enlisted in the Dhaka Stock Exchange. To determine sample the convenience sampling technique is applied that consist of two from Cement, two from Ceramics, two from Food \& Allied, two from Jute, one from Paper and Printing, five from Pharmaceuticals and Chemicals, two from Tannery and ten from Textile. Various journals and research papers, conference and seminar papers, and diagnostic study reports have been accessed in making this study meaningful. The data were analyzed by applying SPSS (Statistical Package for Social Sciences) and MS Excel. The study is not out of any limitation. One of them is that it does not cover all the management accounting techniques rather than some highly applied and fruitful tools.

\section{Management Accounting Techniques and MANUfacturing Companies}

\section{Traditional Management Accounting Tools}

Budgets: Across the world, different researcher and authors have urged that there are numerous benefits from preparing budgets. Firstly budgets help in aggregate planning and accelerate internal collaboration. Indeed these techniques act like glue to align the various departments to ensure effective communication and coordination to utilize organizational resources efficiently. Secondly, budgets also give way for organizations to assign resources more efficiently to achieve organizational goals. Moreover, budgets may also be applied as an instrument to evaluate the divisional or managerial performance (Garrison and Noreen, 2003; Hansen and Mowen, 2002; Hilton, 2002). Recently there have been enormous criticisms leveled at traditional budgets. The Consortium for Advanced Manufacturing-International (CAM-I), an international research consortium of companies, management consultants and academics, claim that the traditional budget stands as an obstacle to efficient management, especially in the present highly competitive dynamic business condition. They argue that the so-called traditional budgeting process is simply an effort in rationalizing the increase and decrease in the previous year's spending in business. Hence, organizations are better off without budgets, particularly as budgets can also create an environment of "going by the book" and grant to a "control by constraint" mechanism. This would, in turn, repress the of an individual's potentiality, creativity and innovativeness (Clarke, 2001).

Surprisingly, in spite of the above criticisms, the exercise of budgets prevails in planning, controlling and evaluation of performance by the managers. It is a significant tool in decision-making especially to enable managers to make more informed decisions. However, it 
is seen that the use of budgets is widespread in Bangladesh. Biswas et al. (2014) have studied 30 manufacturing firms in Bangladesh where they revealed a significant portion of firms use the budget in their daily operation. Yeshmin and Das (2009) investigated the financial institutions in Bangladesh where they found that the managers of these institutions were satisfied in application of budgetary control. Yeshmin and Fowzia (2010) performed a comparative analysis of management accounting practices adopted by manufacturing and service industries in Bangladesh where they saw that the budgetary control was frequently used tool.

Standard costing and variance analysis: The manufacturing environment changes dynamically that tends to diminish the worth of using standard costing and variance analysis (Drury et al., 1993; Lucas, 1997). Earlier, standard costing was regarded as influential technique that accelerates planning and control and also enhances performance evaluation. Also, standard costing also helps in product costing. However, in the present continuously changing manufacturing environment, the advanced facilities of operational control are claimed to be less obvious as standard costing may result in flawed behavior. For instance, a material price variance may influence the purchasing manager to purchase in huge amount to take advantage of discounts but aftermath that would subsequently result in more inventory holding costs. However, this action is inconsistent with the JIT philosophy (Drury, 1999; Hansen and Mowen, 2002). Moreover, monthly standard cost variance reports might be less functional in the current competitive environment.

In addition to the above, the dynamic advancement in the industrial instrument and mechanism the notion of laborintensive industry is replaced by robotics and machine driven facilities. As a result, the computation of labor variances may not be as helpful today as it was in the earlier days. From above criticisms, one would not go for regular application of standard costing mechanism for planning and control purposes in the organization. However, practical results reveal otherwise. Despite the criticisms leveled at standard costing, many organizations still consider standard costing useful for planning and control purposes. In Bangladesh, most of the manufacturing organization applies this technique.

Cost-Volume-Profit (CVP) Analysis: CVP is considered to be one of the most powerful techniques that facilitates managers in planning and decision-making and controlling (Garrison and Noreen, 2003; Hansen and Mowen, 2002). CVP aids managers to perceive the interrelationship between the quantities sold, cost, selling price, and profit. However, due to its narrow assumptions, sometimes some managers are of the judgment that the technique may have very little use in this complex business environment. For instance, the premises that selling price and costs remain constant over the relevant range may not be empirical in this ever- changing competitive business world. Moreover, the supposition that there is no beginning and ending inventories of finished goods may also be unrealistic. As such, the CVP mechanism may gradually lose its significance in complex decision making.

However, empirical results of Bangladesh reviewed reveal otherwise. Various researchers (Yeshmin and Das, 2009; Yeshmin and Fowzia, 2010; Biswas et al., 2014) have found that CVP is a very effective tool to the managers for understanding the relationships among cost, volume, and profit. But it is also noted that some of the firms do not use CVP for short-term decision making. It will be helpful to use CVP to analyze break-even, the margin of safety and to increase profitability (Sharkar et al., 2006).

Performance measurement: Performance evaluation is a significant function of management accounting, distinctly applied in business organizations that have a department wise organizational framework. To calculate the divisional performance the most common cited techniques in our management accounting textbooks are the return on investment (ROI), the residual income (RI) and the economic value added (EVA). In the present time, however, there have been recommendations that more dependence on accounting related measures is not enough to overcome competitive environment. Proponents of the BSC have recommended that nonfinancial techniques should also be considered as an influential tool in decision making. Thereafter, many firms are currently concentrating on both accounting and nonaccounting related measures in measuring the efficiency.

In Bangladesh, this mechanism is widely used by the manufacturing organizations. Biswas et al. (2014) surveyed 30 manufacturing companies to get the empirical scenario of management accounting techniques and the result revealed that shown in the following graph.

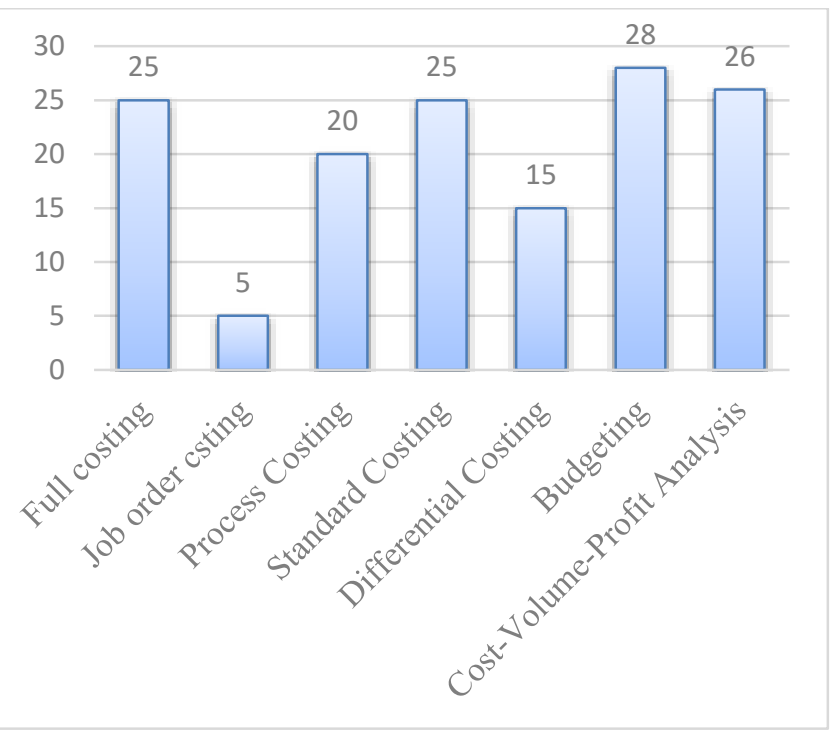

Graph 1: Use of Traditional Management Practices during the year 2008-2012 


\section{Contemporary Management Accounting Tools}

Commonly, we have heard criticisms that traditional management control techniques are constructed too late and at too composite a level to be pertinent for present planning and control decisions (Kaplan and Johnson, 1987). To cope with the challenges of the today's complex business environment, innovative management accounting techniques such as activity-based costing $(\mathrm{ABC})$, target costing (TC), Balanced scorecard (BSC), total quality management (TQM), just in time (JIT), theory of constrain and process reengineering are considered to be more suitable to take effective decisions. In addition to the application of traditional management accounting tools to estimate the performance is no more adequate. Business organizations require focusing on non-financial accounting measures along with financial measures. These innovative techniques help to make sound decisions to minimize cost as well as at the same time add value to the product or service. The introduction of the BSC helps companies to focus on both the financial and non-financial aspects of an organization's functions. The following subsections provide detailed discussions on activity-based costing $(\mathrm{ABC})$, target costing and the balanced scorecard (BSC).

Target Costing (TC): Target costing (TC) provides continuous improvement from the beginning stage both at the design and production phase. It is considered to yield companies with a competitive edge in an organization. Moreover, this will assist companies, particularly Japanese companies, to maintain their competitiveness (Sakurai, 1989). In Bangladesh, amongst the contemporary management accounting techniques, target costing looks promising. Biswas et al. (2014) surveyed among 30 manufacturing organization in Bangladesh and found that on an average only 10 survey respondents reported that their firms use target costing during the period 2008-2012.

Yeshmin and Hossan (2011) studied the relative significance of management accounting techniques in decision-making, and revealed that target costing has an average level of significance (3.6622).

Activity Based Costing (ABC): $\mathrm{ABC}$ has already attained influential recognition amongst managers as a versatile mechanism to aid allocation of overheads with a greater degree of perfection. The subject of more accurate overheads allocation is appropriate because, often when pricing depends on imprecise cost data, the problems/errors will be perpetuated. Besides, ABC eliminates the drawbacks of traditional costing systems by recognizing all the functions and the costs that go into manufacturing the product. Earlier accounting approaches allocate cost on labor hours or machine hours that hardly reflect the cause and effect relationship between indirect costs and individual products. Recent surveys have reported the increasing use of $A B C$, particularly amongst Western enterprises (Scapens, 1991). It has been recommended that the decreasing cost of computing power (Filman, 2000) and the application of enterprise resource planning software may have contributed to this phenomenon. Biswas et al. (2014) surveyed among 30 manufacturing organization in Bangladesh and found that on an average only 6 survey respondents reported that their firms use activity-based costing during the period 2008-2012.

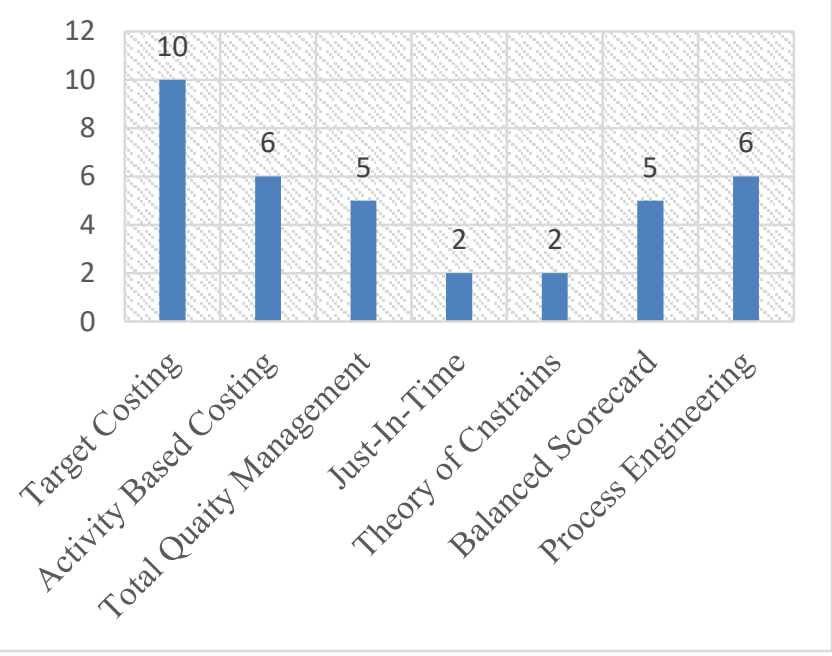

Graph 2: Use of Contemporary Management Practices during the year 2008-2012

Balanced Scorecard (BSC): The Balanced scorecard (BSC) has attained growing admiration at the beginning of its commencement that was introduced by Kaplan and Norton. Renowned scholars and practitioners alike have claimed that depending only on accounting metrics to analyze performance may not be sufficient as a whole. With this in mind, the developers of the balanced scorecard (BSC) have concentrated on four aspects of a business: the internal business process, learning and growth, customers and financial perspectives. Atkinson et al. (1997) claimed that the balanced scorecard (BSC) considered as one of the most influential developments in the arena of management accounting. Hoque and James (2000) are of the opinion that using a BSC.

Therefore, to attain a balance, firms require focusing on all the four aspects of a business. As to be anticipated, Hoque and James (2000) revealed that there is a positive relationship between the company size and BSC application. Thus, the larger the company, the more practical it is to apply BSC to assist their strategic decision making. Joshi's (2001) survey, to some extent, supported this argument. He noticed that large companies favor to utilize newly developed influential management accounting techniques to a larger extent than small and medium-sized companies. Biswas et al. (2014) surveyed among 30 manufacturing organization in Bangladesh and found that on an average only five survey respondents reported that their firms use balanced scorecard during the period 2008-2012. 
Just-In-Time (JIT): JIT is a management philosophy applied by manufacturing companies to increase efficiency and decrease waste by receiving goods only as they are needed in the production process, thereby eliminating inventory costs. This method is useful in the process of production on demand. The survey of Biswas et al. (2014) among 30 manufacturing organization in Bangladesh revealed that on an average only two survey respondents reported that their firms use just in time during the period 2008-2012.

Total Quality Management (TQM): Total Quality Management (TQM) is a management approach that places emphasizes on continuous improvement in quality, in the interest of the organization and that of its customers. TQM focus on long-term success through continuous improvement in different aspects of an organization. It aims to radically transform the organization through progressive changes in the attitudes, practices, structures, and systems. Total quality management transcends the product quality approach, involves everyone in the organization, and encompasses its every function: administration, communications, distribution, manufacturing, marketing, planning, training, etc. Biswas et al. (2014) surveyed among 30 manufacturing organization in Bangladesh and found that on an average only five survey respondents reported that their firms use total quality management during the period 2008-2012.

Theory of Constrain (TC): The Theory of Constraints is a strategy for discovering the most influential limiting factor (i.e. constraint) which hinders to achieve organizational goal. Therefore an organization works to improve systematically until it is no longer the limiting factor. In the manufacturing organization, the constraint is often considered as a bottleneck. It provides a specific mechanism for identifying and eliminating constraints i.e., identify, exploit, subordinate, elevate, and repeat. Biswas et al. (2014) surveyed among 30 manufacturing organization in Bangladesh and found that on an average only two survey respondents reported that their firms use the theory of constrain (TC) during the period 2008-2012.

Process Engineering: Process Engineering is a management technique to evaluate the current business process and develop a dynamic new method to enhance productivity, efficiency and reduce operational cost. Biswas et al. (2014) surveyed among 30 manufacturing organization in Bangladesh and found that on an average only six survey respondents reported that their firms use total process engineering during the period 2008-2012.

Indeed process engineering revises workflows to optimize processes and eliminate non-value-added activities. A comprehensive re-engineering project could result in the complete replacement of an existing process. It fully integrates all the wings of an enterprise with the latest information technology to get the best outcome.

\section{FINDINGS OF THE STUDY}

This section discusses issues related to the practice of management accounting techniques among the manufacturing companies. The sound management of financial operations of an organization ultimately depends on the top management. The findings are presented below:

- The majority (70\%) of the respondents have agreed that top-level management is responsible for selecting management accounting techniques for running regular activities.

- The survey revealed that almost all the manufacturing companies have a separate top-level management including CEO to determine management policies.

- The majority (97\%) of the respondents agreed that their organizations have at least one or more traditional management accounting techniques to deal with business functions.

- The survey unveiled that $95 \%$ of the respondents are reluctant to introduce new management accounting techniques as they are unaware of the potentiality.

- $\quad 90 \%$ of the respondents have agreed that to initiate new techniques in management, they have to convince the top-level management the effectiveness of new one over the old one.

- The survey disclosed that low majority (28\%) of sample organizations have more than two contemporary monument accounting techniques in operation.

- It is also explored by the survey that the knowledge of advanced management accounting tools is mandatory before any further application in daily operation and without proper knowledge it is impossible to go forward. Besides majority of the top-level managements are quite traditional in mind and they are reluctant to experiment the new mechanism in decision making.

- It is also seen that the entrepreneurs, investors, directors rely on the widely successful techniques. Even if the management initiates any changes in existing mechanism the directors and other decision makers crate a block. This is done to avoid risk of introducing new mechanism. Actually, the majority believe in old techniques.

- The study also uncovered that the majority of the organizations (90\%) apply the most common traditional techniques where Cash-flow Statement Analysis, Ratio Analysis, Budgetary Control, CVP Analysis, Variance Analysis, Standard Costing and Variable Costing are relatively highly applied techniques.

- The survey also disclosed that the relatively moderate applied techniques are Target Costing, Absorption Costing, Inter-firm Comparison, Total Quality Management and Activity Based Costing. A less than $35 \%$ of respondents apply these techniques regularly.

- The study revealed that the low extent uses (5\%) techniques are Balance Scorecard, Differential Costing, 
Just-In-Time, Opportunity Costing, Theory of Constrain, Responsibility Accounting, Management by Exception, Process Reengineering, and Kaizen Costing.

- The survey divulges that majority of the respondents agreed that top their organizations required to arrange tanning programs, a workshop for the toplevel management to explore the new business tools for efficient management.

Moreover, the survey result also revealed the following descriptive statics indicating the application of management accounting techniques among the manufacturing organizations.

Table 1: Ranking and Descriptive Statistics of Management Accounting Techniques

\begin{tabular}{|l|c|c|}
\hline \multicolumn{2}{|c|}{ Techniques 1: High extent of use } \\
\hline \multicolumn{2}{|c|}{ Mean Score } & Rank \\
\hline Cash flow Statement Analysis & 4.3108 & 1 \\
\hline Ratio Analysis & 4.2432 & 2 \\
\hline Budgetary Control & 4.2027 & 3 \\
\hline CVP Analysis & 4.0946 & 4 \\
\hline Variance Analysis & 4.0541 & 5 \\
\hline Fund Flow Analysis & 4.0540 & 6 \\
\hline Standard costing & 3.8514 & 7 \\
\hline Variable Costing & 3.7568 & 8 \\
\hline \multicolumn{2}{|c|}{ Level 2: Moderate extent of use } \\
\hline Target Costing & 3.6622 & 9 \\
\hline Absorption Costing & 3.5405 & 10 \\
\hline Inter-firm Comparison & 3.4595 & 11 \\
\hline Total Quality Management & 3.4459 & 12 \\
\hline Activity Based Costing & 3.3919 & 13 \\
\hline \multicolumn{2}{|c|}{ Level 3: Low extent of use } \\
\hline Balance Scorecard & 3.3514 & 14 \\
\hline Differential costing & 3.2973 & 14 \\
\hline Just In Time & 3.2703 & 16 \\
\hline Opportunity Costing & 3.1757 & 17 \\
\hline \multicolumn{2}{|c|}{ Lowest extent of use } \\
\hline Theory Of Constrain & 3.0946 & 18 \\
\hline Responsibility Accounting & 2.9865 & 19 \\
\hline Management By Exception & 2.9730 & 20 \\
\hline Segment Reporting & 2.8919 & 21 \\
\hline Process Reengineering & 2.7973 & 22 \\
\hline Kaizen Costing & 2.3649 & 23 \\
\hline
\end{tabular}

Source: Developed by the author.

The above table merely indicates the relative significant tools of management accounting and the ranks of these techniques where the traditional techniques prevail in prime significance and the contemporary techniques are relatively downwards.

\section{RECOMMENDATIONS}

Management accounting is a very influential decisionmaking mechanism in today's competitive business world. It is very crucial to use different techniques to get the key information to take the best possible decision in order to achieve organizational goals. Although only traditional techniques are highly used to interpret business information for best decision in Bangladesh whereas developed countries use the advanced techniques to get the best result. So it is high time to adopt the contemporary tools more and more along with the traditional techniques. After analyzing the all the major and associated findings, the following recommendations have been made to enhance management accounting practices in Bangladesh.

- As most of the companies heavily rely on some traditional techniques, it indicates that the usability of modern management accounting techniques need to be emphasized. The concerned higher authorities who are engaged in policy development should arrange awareness program and proper training facilities.

- As Institute of Cost and Management Accountants (ICMAB) is the highest professional body that deals with management and manufacturing mechanism. Therefore, ICMAB should step up to create awareness among the top-level managers about the new and contemporary management accounting techniques by arranging different knowledge events.

- The manager should be more flexible about the adoption of new techniques as the business environment is changing its shape and becoming more dynamic and highly competitive.

- Most of the companies who highly emphasize traditional management accounting techniques like budgeting, standard costing should focus on other advanced tools to deal with new situations.

- Organizations should slowly adopt new sophisticated techniques like JIT technique to improve the business process by eliminating additional investment in storing materials that can help to increase return on investment. So manufacturing company may try just in time slowly in the production process.

- To cope with the competitive free market it is significant to offer the product the best economic price focusing the competitors and to do so TQM, and Target Costing are the best weapon to utilize.

- Most of the manufacturing organizations apply standard costing by historical information. Indeed standards are determined considering past data, but as the future is always uncertain, it is recommended to determine standard by estimating future value and other relevant circumstances.

- To accelerate the performance of the production process it is recommended that the application of contemporary or innovative techniques should be adopted with priority.

- It is seen that most of the organization develop policy focusing on day to day activities rather than log run sustainability. However the perception of continuous development in terms of reducing time and cost should also be developed among the officials. 
- The application of management accounting techniques highly influenced by the perception and management style of top-level management, internal policy, and external factors. Therefore, management should focus on those techniques ensures continuous and sustainable growth by eliminating cost.

\section{Conclusion}

Management accounting techniques are relative which largely depend on several issues like management style, organizational culture and so on. The world is changing fast, and management techniques are also changing regularly to deal with new competitions. Effective practices of management accounting techniques are very much essential to achieve and maintain sustainable development. Therefore it is significant to take the necessary steps to provide efficient management through the application of highly effective techniques. This study shows the top-level management is primarily and indeed ultimately responsible for developing the policy to adopt necessary tools to make management system swift. However, the overall evidence indicate that the excessive reliance on traditional techniques than that of contemporary management accounting tools which are very slowly being adopted in Bangladesh. For example, the greater emphasis in Bangladesh is on traditional management accounting techniques. It was perceived by the survey respondents that the benefits accruing to traditional management accounting practices were high Yeshmin \& Hossan (2011). Another influential issue may be the high costs associated with implementing contemporary management accounting techniques as it is associated with some sort of trading and development initiatives for employees. Bangladeshi companies sensed that it is rather costly to establish new management accounting techniques. As observed in Table I, the respondents envisaged traditional tools like CVP, standard costing and traditional budgeting over a long period. Tho et al. (1998) provide various reasons as to why traditional management accounting practices are still widely used in developing countries: the lack of awareness of new techniques, the lack of expertise and, perhaps, more importantly, the lack of top management support. Additional factors include the high cost of implementation and the fact that there was "no reason to change" from the traditional technique to the new tool.

This study is not out of any pitfall. Firstly, the primary limitation of this study the size of the companies surveyed, sampling procedures and types of measures may have key implications on the reported findings. These issues may pose a significant threat to the validity of the results (Guilding et al., 1998). Further, a rigorous statistical analysis of the results of earlier studies is lacking. The findings are limited to percentages, frequency, and rank. Finally, future studies should endeavor to investigate specific factors as to why do firms in Bangladesh are not fully adopting newly developed management accounting techniques such as ABC, JIT, Target Costing, etc. What are the obstacles to implementing such innovative techniques? Is culture predominant factor prevailing? As far as this review is concerned, firms Bangladesh are consistently applying on board traditional management accounting practices despite the fact that contemporary techniques are more effective to some extent. Thus, are current management accounting practices being strongly driven by factors at the macro level where considerable global pressures lead to similar practices across countries (Grandlund and Lukka, 1998). Simultaneously, the global similarities perspective of management accounting practices is an area that is worth examining. Therefore, future research on this subject should address something more like the relationship between profitability with management accounting techniques. Besides hypothesis can be developed to make further research more fruitful.

\section{REFERENCES}

Abdul Rahman, I.K., Abdul Rahman, A.Z., Tew, Y.H. and Omar, N. (1998), "A survey on management accounting practices in Malaysian manufacturing companies", Management Accounting Practices Paper 3, Concurrent session IC, International Management Accounting Conference, National University of Malaysia, Selangor.

Atkinson, A.A., Balakrishnan, R., Booth, P., Cote, J.M., Grout, T., Mali, T., Roberts, H., Ulan, E. and Wu, A. (1997), "New directions in management accounting research," Journal of Management Accounting Research, Vol. 9, pp. 80-108.

Biswas, M.R., Akterujjaman S.M., Yasmin, A. (2014), "Management Accounting Practices in Manufacturing Business Firms in Bangladesh", BGMEA University of Fashion \& Technology, Vol. 2, pp. 87-97.

Bromwich, M., and Bhimani, A. (1994), Management Accounting: Pathways to Progress, Chartered Institute of Management Accountants, London.

Choi, D.S. and Mueller, G. (1992), International Accounting, 2nd ed., Prentice-Hall, Englewood Cliffs, NJ.

Clarke, P. (2001), "Traditional budgeting: help or hindrance?", Accountancy Ireland, pp. 12-15.

Drury, J.C. (1999), "Standard costing: a technique at variance with modern management?", Management Accounting, pp. 56-8.

Drury, J.C., Braund, S., Osborne, P. and Tayles, M. (1993), A Survey of Management Accounting Practices in UK Manufacturing Companies, Certified Accountants Educational Trust, London.

Filman, H. (2000), "Manufacturing masters its ABCs: activitybased costing can help boost profits," Business Week, No. 3693, p. 86.

Firth, M. (1996), "The diffusion of managerial accounting procedures in the People's Republic of China and the influence of foreign partnered joint ventures," Accounting, Organisations and Society, Vol. 21 No. 7/8, pp. 629-54.

Garrison, R.H., and Noreen, E.W. (2003), Managerial Accounting, 10th ed., McGraw-Hill, New York, NY. 
Ghosh, B.C., and Chan, Y.K. (1996), "Management accounting practices in Singapore: the state-of-the-art," unpublished manuscript, Nanyang Business School, Singapore.

Ghosh, B.C., Chung, L.H. and Wan, C.Y. (1987), "Management accounting in Singapore," Management Accounting, pp. 28-30.

Grandlund, M. and Lukka, K. (1998), "It's a small world of management accounting practices," Journal of Management Accounting Research, Vol. 10, pp. 153-79.

Guilding, C., Lamminmaki, D. and Drury, C. (1998), "Budgeting and standard costing practices in New Zealand and the United Kingdom," International Journal of Accounting, Vol. 33 No. 5, pp. 569-88.

Hansen, D.R., and Mowen, M.M. (2002), Management Accounting, 5th ed., South-Western College Publishing, International/Thomson Publishing, Cincinnati, $\mathrm{OH}$.

Hilton, R.W. (2002), Managerial Accounting: Creating Value in a Dynamic Business Environment, 5th ed., McGraw-Hill Irwin, New York, NY.

Hoque, Z. and James, W. (2000), "Linking balanced scorecard measures to size and market factors: impact on organizational performance," Journal of Management Accounting Research, Vol. 12, pp. 1-17.

Joshi, P.L. (2001), “The international diffusion of new management accounting practices: the case of India," Journal of International Accounting, Auditing and Taxation, Vol. 10, pp. 85-109.

Kaplan, R.S. (1983), "Measuring manufacturing performance: a new challenge for managerial accounting research," The Accounting Review, Vol. 58 No. 4, pp. 686-705.

Kaplan, R.S. and Johnson, H.T. (1987), Relevance Lost: The Rise and Fall of Management Accounting, Harvard Business School, Boston, MA.

Lucas, M. (1997), "Standard costing and its role in today's manufacturing environment," Management Accounting, Vol. 75 No. 4, pp. 32-4.
Radebaugh, L.H. and Gray, S.J. (1993), International Accounting, and Multinational Enterprises, Wiley, New York, NY.

Sakurai, M. (1989), “Target costing and how to use it," Journal of Cost Management, pp. 39-50.

Scapens, R.W. (1988), "Research into management accounting practice," Management Accounting, December, pp. 26-8.

Scapens, R.W. (1991), Management Accounting: A Review of Contemporary Developments, Macmillan Education Ltd, London.

Sharkar, M. Z. H., Sobhan, M. A., Sultana, S. (2006), “Management Accounting Development and Practices in Bangladesh", BRAC University Journal, vol III, no. 2, pp. 113-124

Sulaiman, M., Nik Ahmad, N.N., Alwi, N. (2002), "Management accounting practices in Malaysia: a survey of the industrial and consumer products sectors," unpublished research report, International Islamic University, Kuala Lumpur, Malaysia.

Tho, L.M., Md. Isa, C.R. and Ng, K.T. (1998), "Manufacturing environment, cost structures and management accounting practices: some Malaysian evidence," Akauntan Nasional, August.

Willett, R., Nishimura, A. and Baydoun, N. (1997), "Reflections on the relationship between culture and accounting practices in the Asia Pacific region," in Baydoun et al. (Eds), Accounting in the Asia Pacific Region, Wiley, New York, NY.

Yeshmin Farjana and Fowzia Rehana 2010, "Management Accounting Practices: A comparative analysis of manufacturing and service industries," Journal of Centre for Socio-economic Research, ASA University Bangladesh, Vol. 4, No. 1

Yeshmin Farjana and Das Sumon 2009, "Management Accounting Techniques: An appraisal of managerial performance of the financial institutions in Bangladesh," Institute of Chartered Secretaries and Managers of Bangladesh (ICSMB), Vol: XI, Issue: 3.

Yeshmin, F. and Hossan, M. A. (2011). "Significance of Management Accounting Techniques in Decision-making: An Empirical Study on Manufacturing Organizations in Bangladesh," World Journal of Social Sciences, 1, 1: pp. 148 - 164.

Appendix 1: List of Sample Manufacturing Companies

\begin{tabular}{|l|l|}
\hline Aramit Cement Limited & Keya Cosmetics Ltd. \\
\hline Confidence Cement Ltd. & Apex Footwear Limited \\
\hline Monno Ceramic Industries Ltd. & Apex Tannery Limited \\
\hline Shinepukur Ceramics Limited & Aman Cotton Fibrous Limited \\
\hline Bangas Ltd. & Al-Haj Textile Mills Limited \\
\hline Fine Foods Limited & Alltex Industries Ltd. \\
\hline Jute Spinners Ltd. & Apex Spinning \& Knitting Mills Limited \\
\hline Northern Jute Manufacturing Co. Ltd. & Argon Denims Limited \\
\hline Bashundhara Paper Mills Limited & The Dacca Dyeing \& Manufacturing Co. Ltd. \\
\hline ACI Formulations Limited & Delta Spinners Ltd. \\
\hline ACI Limited & Envoy Textiles Limited \\
\hline Beximco Pharmaceuticals Ltd. & Familytex (BD) Limited \\
\hline The IBN SINA Pharmaceutical Industry Ltd. & Saiham Textile Mills Ltd. \\
\hline
\end{tabular}

Online Archive: https://abc.us.org/ojs/index.php/abr/issue/archive 